\title{
THE TENSION BETWEEN HUMANISM AND SCIENCE: SOCIOLOGY IN THE 1980s*
}

\author{
Joseph R. Gusfield \\ University of California, San Diego
}

Mid-American Review of Sociology, 1980, Vol. V, No. 1:1-14

Although we talk a great deal about prediction as an aim of social science we practitioners of sociological science have never been very successful in peering into the future and seeing what is to be. Yet soothsaying is an ancient if not always honorable profession and I have incautiously rushed in by agreeing to accept the charge of this presentation. To save my rash action from being an empty performance I will try to use the format of crystal gazing as a device within which to raise some questions of theory and method which I believe are both persistent in sociology and reemerging now and in the coming years as central points of intellectual conflict.

My theme is the recurrent issue of the image of human behavior and the metaphors or models which we sociologists use to study, understand and explain our subject matter. In my judgment the two models of a humanistic view of human action and a scientific one have continuously been offered. Each has been drawn from its own tradition, differing from the other in fundamental ways. The Humanistic model has been drawn from literature, art, philosophy, and history, the scientific model from physics, biology and chemistry. Science has stressed the deterministic character of cause-effect relationships and provided a methodology for discovering the operation of laws or propositions of human behavior. Humanistic studies have emphasized the self-conscious, selecting and unpredictable character of human action. Science has sought generalization; Humanism avoids it. Such models are, of course, dangerous and, especially for the

*This paper is based on an address before the Kansas Sociological Association, Lawrence, Kansas, November 1, 1979. 
Mid-American Review of Sociology

the Humanist, deeply misleading. I use them both as heuristic images, to get us into my paper, and as images which, like metaphors, are important for their impact on thought.

Some years ago, my colleague Bennett Berger published a paper in which he explained the antipathy of humanistic scholars to sociology as a form of resentment against the loss of the humanist's claim to public attention in the arenas of politics, morals and public opinion. That place had been taken by social scientists, including sociologists (Berger, 1957). My thesis in this paper is that the tide has ebbed. Sociology is today and will be in the coming decade receding from its importance as a source of policy and public opinion. In modern societies the authority of the Scientific model is losing its credibility as a basis of social control. In intellectual life the Humanistic model is assuming greater voice and a more receptive audience. The tension between Humanism and Science is again vibrant and obtrusive on our sociological stage.

\section{THE DECLINE OF AUTHORITY}

I am only briefly turning away from my introductory remarks about models and metaphors of Humanism and Science in order to provide the scene within which I imagine sociology will play out its role in the coming decade. That scene must be perceived against the substantive concerns that have been given great attention in the realms of public action and policy during the 1970s. These, I am bravely prophesying, will be central in substantive research and writing in the $1980 \mathrm{~s}$. Both are connected with the declining legitimacy of political and scientific authority.

The history of sociology is conventionally approached through the analysis of major theoretical perspectives and theorists. "From Marx to Parsons and beyond" might be the general format. Texts which describe theories at lesser levels, closer to the Mertonian "middle range," similarly tend to remove theories from the environments in which they developed and with which they tried to cope. For me, this is a mistake. A history of sociology needs to be attuned to the substantive considerations that have governed the appearance of theories and the changes in

\section{Humanism and Science}

perspectives and interests. An understanding of theories of social movements, an area in which I have worked, must give consideration to how a concern for political liberalism among both its defenders and its attackers has governed the choice of topics and set in motion certain theoretical concerns. In recent years, for example, social movements have put at the center of study such topics as the nature and emergence of violence and the occurrence and fate of social movement organizations (Tilly, 1978; Gamson, 1975; McCarthy and Zald, 1973; Oberschall, 1973). Such intellectual interest must be seen as responses to problems set by historical events such as the protest movements and anti-poverty campaigns of the 1960s. In this fashion sociological topics of substance reflect the pressing problems and issues of the previous decade (Gusfield, 1978). The current heat of debate about the value of "labeling theory" has lost sight of the way in which that body of ideas emerged as a response to a period, in the 1950 s and early 60 s, in which new areas of public concern assumed deviance status-areas of "victimless crimes," such as drug use, and of "moral stigma," such as mental health and alcoholism. These had become centers of public policy interest. The effort to treat "labeling theory" as a general theory of deviance seems misguided if such considerations are ignored (Gove, ed., 1975; Becker, 1973:Ch. 10).

One of the major intellectual revisions of the 1970s has been the rediscovery of the State. Among the Marxists, where the State has long been viewed as an epiphenomenon, a "reflection" of class dominance, it has come to be seen as an independent force in social change and societal development (Buroway, 1979). Even among political scientists, the era of sociological analysis of politics has receded. At the same time the authority and efficacy of the State as a center of direction and of legal enforcement is problematic. The rise of ethnic nationalisms, for example, has raised issues of national community to a focal point in many countries, including the United States (Hechter, 1975; Tilly, 1969; Blauner, 1972). Distrust of government and law is a facet of the second, more vital source of the decline of authority in the United States-the rising distrust of science and technical expertise. 
Both political and scientific authority are under challenge. The first diminishes the legitimacy of national symbols and national rules-making. It expands the effectiveness of local, primordial and personal ties at the expense of national, public and universal ones. The second undermines the legitimacy of the technologies by which experts claim authority.

The field of medicine is an apt example of the declining authority of the expert. The distrust of the medical profession, latent in the American public (Kresiberg; 1972), has become more lively and evocative in the 1970s. Demands for participation in medical boards, efforts to control medical institutions through legislation, and the rise of medical movements outside of the medical profession are all instances of the growing unwillingness of patients to accept medical advice. Sociologists contributed to the developing challenge to the credibility of expertise by examining the cultural assumptions and social power of physicians, psychiatrists and the medical profession (Goffman, 1961; Freidson, 1970; Szasz, 1961).

The challenge to the dominance of the Scientific model in sociology is set in this historical current of attack on the validity of Science and Technical knowledge as a source of public authority. It is this social trend that provides the scene against which the substantive and methodological concerns of the 1980s are likely to appear. Intellectual currents, which I will discuss later, are also of significance and provide the Humanistic alternative with greater credence than it has had in recent decades.

\section{SOCIOLOGY AND THE WELFARE STATE}

Both directly and indirectly, American sociology is a product, perhaps even a cause, of the rise of the welfare state (Gouldner, 1970:Ch. 3, 9). That political movement toward greater public responsibility for the vicissitudes of the free market has proliferated the transformation of personal situations into public problems; there is greater concern for the responsibilities to ameliorate conditions and persons suffering from social, physical and moral "ills" (Briggs, 1961; Wilensky and LeBeau, 1958).
In his classic paper "Social Problems That Are No More," Ian Weinberg has described the emergence of attention to problems conceived as public concerns and the development of referral occupations to facilitate solutions:

In a modern society it is accepted that the family has not the human, material or organizational resources to deal with problems such as illness or crime. The educable, the sick, the criminal are quickly removed from the family. Modernization means that private, family problems should quickly become public and social problems. Professionals exist within service organizations to receive those persons whom the family by definition cannot handle. .. . A 'referral structure' comes into existence (Weinberg, 1974:41).

This professional "referral structure" is the necessary backing for the demand to place sociology in the common curriculum of higher education, a demand that has been essential to the great growth of American sociology as mass higher education that has characterized American education since 1939. It is sociological thought and research that, along with clinical psychology, has provided a basis for the theoretical and descriptive claims of many of the new professions and their acceptance within the lay public. The matter can be understood by an examination of the nature of professions in modern life (Hughes, 1958; Freidson, 1961; Gusfield, forthcoming).

Social work, counselling, criminology, psychiatry, community organizers, educational guidance personnel are a few of the "troubled persons" occupations. Along with the organizers and functionaries of social movements these have spurred an orientation to public problems and the needed research accompanying them. Along with older occupations, they have made a claim to provide a service based on knowledge and skill acquired through schooling. They claim to be practitioners of one or another social technology. It is in aiding and supporting the rise of social technologies that sociology has built a bridge to and from the welfare state and the arena of public issues and problems. 
What sociology brings to public problem concerns is a body of research and writing that purports to bring credibility to what experts in applied fields know and that establishes the conclusions of sociologists about public problems as valid and reliable. They contribute theories of society that explain and direct public problems along lines of credible understanding (Gusfield, 1979). Is youth protest gaining attention or divorce assuming public worry? The sociologist is there to tell the public why it is and how it may be alleviated. Here what Bennett Berger wrote and to which I alluded earlier is quite plain: The sociologist as scientist has driven out the humanist as moral critic in the race to be prophet and point for contemporary societies.

It is precisely here, in its claim to develop a theoretical science, that sociology has performed a significant role in the technological provision of welfare. The "social technologies" which the experts have studied and which constitute their claim to authority have, in these new occupations, been supported by or substantively provided by the theories and research of sociologists. This is also the case in older occupations where education has been crucial to certification. The trained person in "social" occupations either has been educated in sociological concepts and methods or in a "state of the art" that has been dependent on the sociologist's theories and methods.

The crisis in the authority of these "social technologies" and the professional expertise claimed by those trained in them is also the crisis of sociology as Science. In criminology, for example, the movement away from rehabilitative policies and penology is a repudiation of sociological conclusions ( $N$. Morris, 1974; J. Wilson, 1975). There, as in other social problems areas, the results of using sociological findings has not been salutary or effective. Mental health, alcohol, race relations, juvenile delinquency, and poverty have hardly been affected even where the sociologist's findings have been adhered to. The instance of segregationist issues is a case in point. The swirl of findings, counter-findings and claims not upheld by events has contributed to the general movement away from centralized and elite authority in the United States. The authority of Science as grounds for professional license has been deeply weakened. The distrust of practitioners by clients and of experts by laypersons has always been a latent aspect of professionalism. In the past decade it has become so manifest as to constitute a movement. Again the critics of the medical model, perhaps the strongest of the professional claims, represent an intellectual form of this revolt (Carlson, 1975; lllich, 1976). The rise of the alternative schools movement is another indication of the rebellion against the technician in education.

In field after field, the demand for participation in policy on the part of the nonspecialized and the uneducated negates the importance of social technologies as a basis for the claim to authority. Experience and emotional commitment come to be assessed as significant elements in coping with social problems. The effort to provide a set of objective and scientifically validated sets of theories and substantive conclusions has floundered.

One motif of the 1970s has been the loss of faith in the saving powers of technology and science to achieve progress and welfare. The ecological movement has provided a criticism of economic growth through technical knowledge-until now the gospel upon which so much of American life has been founded. The turn toward fundamentalist and eastern religions carries with it an implicit repudiation of the logic of science and a quest for emotive experience as "truer" and more compelling than the method of causal analysis. Such turns away from the validity of scientific thought have occurred before during the period in which sociology has been an accepted part of the intellectual landscape, but not so strongly as now (Sklar, 1971).

For much of social science, the image of the human being has been that of a causally-determined animal, about whom laws can be discovered and propositions drawn. This undergirds the characteristic social engineering bent of both reformers and radicals in orthodox liberal and radical thought (Gusfield, 1973; Stoll, 1975). The opposing conception of a self-ordered, choosing being comes into prominence as the claims to social technology become less trustworthy. W.H. Auden's admonition that "Thou Shalt Not Commit a Social Science" has more resonance in this context of the 1970s than it did in a more science-idolizing decade. 


\section{MOVEMENTS OF IDEAS: THE CRITIQUE OF POSITIVISM}

A conception of the limits of the Scientific model has always existed among social scientists. The verstehen viewpoint of Max Weber and the Geistesswishenschaften perspective have conceived of human beings as less capable of being explained and predicted than the causal models of quantitative, experimental and mathematical models would recognize (H.S. Hughes, 1958; Weber, 1949). So too, the, symbolic interactionists, stressing the role of language and interaction in developing and defining action, have focused attention on the differences between animals as gesturing organisms and humans as symbol producing animals (G.H. Mead, 1934; Blumer, 1969). Both streams have greatly emphasized both the crucial importance for the observer of knowing the meaning of objects and events and the effect of the process of communicating on the data itself. Seeing events from the standpoint of the subject requires the "scientist" to understand the ambiguity of defining the stimulus in any stimulusresponse syndrome (Chomsky, 1959).

More recently the challenge to the positivistic view of a technical science has come from within the humanistic disciplines. Building upon phenomenological philosophers and the works of Alfred Schutz, the ethnomethodologists and the new orientations toward a sociology of knowledge have given us a new approach to the ideas of social order (Garfinkel, 1967; Berger and Luckmann, 1967; Cicourel, 1974). Rather than assuming the existence of a known and assumed world to which humans adjust, they have taken that world as their subject and sought to understand how human beings construct and define reality. In the language of ethnomethodology, they have made what was an indispensable "resource" into a problematic "topic." In taking as their topic the methods by which subjects create their realities (an "ethnomethod"), they have also focused on how social scientists in turn interpret and create the data that are gathered by their methods of categorizing, naming, and abstracting from particculars.
This absorption with language is perhaps the common mark of the new movements, which, following Anthony Giddens, I call the interpretive or cultural movement in the social sciences. That direction is probably most influentially seen in that confluence of literature, cultural anthropology and linguistics which has emerged in structuralism. Beginning in linguistics and literary analysis with Frederic Saussure and Roman Jakobson, it reaches its most influential zenith for social studies in the work of Claude Levi-Strauss (Levi-Strauss, 1962, 1967; Leach, 1970; Hawkes, 1977). The search for interpretive principles, for the structure underlying myth, ritual and social patterns, represents a circular turn toward the importance of symbolic representations as equal and even anterior to social structure in understanding human action (Geertz, 1974). Social structure subsists in the ideas about that structure, the cultural forms in which we represent them rather than the actions themselves (Leach, 1959).

This being so, the ways of the social student of "society" are also part and parcel of the forms through which he/she examines the world. The work of Foucault has been especially influential in treating basic "realities" as cultural products (Foucault, 1970; H. White, 1973). Most recently even the contents of science, its symbolic products, have also been so treated. Sociology of knowledge had exempted science and its method from sociological analysis, but what David Bloor calls "the hard case" has also come into the field of sociology of science (Bloor, 1976; Gusfield, 1976, forthcoming; LaTour and Woolgar, 1979).

In taking ideas and culture as something more than epiphenomenal reductions from the play of interests around economic and material concerns, sociologists have been forced to revise the fundamental sociology of knowledge with which in the past they have approached the analysis of the ideational. The disquiet surrounding the notion of ideology is one root of the rediscovery and renaissance of Marx the younger and the Hegelianizing of Marx that has emerged as so crucial a wing of NeoMarxism since Lukacs (Marcuse, 1964; P. Anderson, 1976).

It is among the critical theorists that the relation between the anti-professional movements discussed above and the movements of 
ideas among social scientists can be best observed. In examining contemporary culture, the "privileged" role of science and technology has been analyzed in its relation to political and economic institutions. Habermas and Marcuse are particularly identified with this effort to rethink both the inevitability and the industrial, rather than capitalistic, status of bureaucracy as technology in Weber's writings (Habermas, 1970; Marcuse, 1964, 1968).

Within the ambit of critical theory, social science also emerges as a target of critical appraisal. What the critical theorists are about is continuous with the general character of interpretive sociologies. It undermines the claims of positivistic social science to stand "outside" other forms of thought as detached, free of value-assumptions and hence forming the foundations of objective knowledge, unassailable as the product of a particular commitment to a political, social or other world-view.

\section{TOWARDS A HUMANISTIC SOCIOLOGY}

Social science has been the grounds for the adequacy of a technical knowledge. That knowledge granted to professionals who take people as clients a claim to a legitimate position as experts who possess a knowledge and wield a skill that commands authority. That science, and its resulting social technologies, has been built upon an image of human beings and of social organization which, I assert, is more difficult to maintain today than it was in the metaphorical yesterday. For the reasons developed above, the Scientific image is being tempered by a more Humanistic one.

By "Humanistic" I do not mean the kind of paradigm sometimes used to accuse Science of a lack of concern with human values or a callous indifference to its effects (Hoult, 1979). Instead I understand by this term a point of view asserting that the unique character of human beings, both as subjects of social science and as social investigators, makes it impossible to borrow the methodologies and imagery of Science in studying human behavior.

Chief among these considerations is the language-using and symbol-choosing nature of human action and understanding.
Meaning arises in the interaction of an external world with the ways in which that world is symbolized and characterized (Mead, 1934; Piaget, 1971). Because of this, a stimulus-response scheme cannot be used to depict or analyze human behavior. The stimulus is itself, in whole or part, a product of the responder (Chomsky, 1959). Culture-the imputation of categories of cognitive and moral character, intervenes between events, actions, and objects to define them. In all behavior, including the acts of social scientists and even natural scientists, there are choices that are not fully coerced or compelled by the nature of the objective reality (Gusfield, forthcoming; Bloor, 1976). An element of moral or political conflict cannot be escaped by scientific authority.

The image of human behavior and of society that will assume greater prominence in the coming years is a more fluid, less deterministic, and less predictable one than has heretofore dominated sociology and social science. It will be more difficult to talk about "society" as if we can reify that concept into a tangible and palpable fact. We will be more wary of making ideal types into definitive institutions and ignoring their "ideal" nature. We are more likely to find affinities with the literary critics and the philosophers in recognizing the artistic and creative nature of our work as interpreters more than discoverers.

Just as the Marxists have rediscovered and promoted the early Marx, so has much of sociology stood Marx on his head, reversing the famed upset of Hegel. Consciousness has returned and with it the utopianism and political choice which science and technology had hoped to dismiss. That sense of certainty and neutrality which has buoyed the sociologists in their claim to a public position is less likely to be evidenced in this new decade.

\section{REFERENCES}

Anderson, Perry

1976 Conditions of Western Marxiam. London: NLB.

Becker, Howard S.

1973 Outsiders. New York: The Free Press.

Berger, Bennett

1957 "Sociology and the intellectuals." Antioch Review, Autumn. 
Mid-American Review of Sociology

Berger, Peter and Thomas Luckmann

1967 The Social Construction of Reality. Garden City, N.Y.: Doubleday Anchor Books.

Blauner, Robert

1972 Racial Oppression in American. New York: Harper and Row.

Bloor, David

1976 Knowledge and Social Imagery. London: Routledge and Kegan Paul, LTD.

Blumer, Herbert

1969 Symbolic Interactionism. Englewood Cliffs, N.J.: Prentice-Hall.

Briggs, Asa

1961 "The welfare state in historical perspective." Archives of European Sociology $11: 221-258$.

Burawoy, Michael

1979 "Contemporary currents in Marxist theory." In Scott McNall, (ed.), Theoretical Perspectives in Sociology. New York: St. Martin's Press.

Carlson, Rick

1975 The End of Medicine. New York.

Chomsky, Noam

1959 "Review Essay of B.F. Skinner, Verbal Behavior." Language 35: 26-56.

Cicourel, Aaron

1974 Cognitive Sociology. New York: The Free Press.

Foucault, Michel

1973 The Order of Things. New York: Vintage Books.

Freidson, Eliot

1972 The Profession of Medicine. New York: Dodd, Mead \& Co.

Gamson, William

1975 The Strategy of Social Protest. Homewood, Ill.: Dorsey.

Garfinkel; Hărold

1967 Studies in Ethnomethodology. Englewood Cliffs, N.J.: PrenticeHall.

Goffman, Erving

1961 Asylums. Garden City, New York: Anchor Books.

Gouldner, Alvin

1970 The Coming Crisis of Western Sociology. New York: Basic Books.

Gove, Walter (ed.)

1975 Labeling of Deviance. New York: Halsted Press.

Gusfield, Joseph

1973 Utopian Myths and Movements in Modern Societies. (Module) Morristown, N.J.: General Learning Press.

1976 "The literary rhetoric and science: comedy and pathos in drinking driver research." American Sociological Review 41:16-34.
Humanism and Science

1978 "Historical problematics and sociological fields: American liberalism and the study of social movements." In R.A. Jones (ed.), Research in Sociology of Knowledge, Sciences and Art. volume I. Greenwich, Conn.: JAI Press Inc.

1979 "The sociological reality of America: an essay on mass culture." In H. Gans, N. Glazer, J. Gusfield, and C. Jencks (eds.), On the Making of Americans: Essays in Honor of David Riesman. Philadelphia: University of Pennsylvania Press.

forth- The Culture of Public Problems: Drinking-Driving and the Sym-

coming bolic Order. Chicago: University of Chicago Press.

forth- "The emergence of problem-solving professions: the case of the coming alcoholism industry." In Michael Lewis (ed.), Research in Social Problems and Public Policy, vol. 2, Greenwich, Conn.: JAI Press Inc.

Habermas, Jurgen

1970 "Technology and science as ideology." In Towards a Rational Society. Boston: Beacon Press.

Hawkes, Terence

1977 Structuralism and Semiotics. Berkeley and Los Angeles: University of California Press.

Hechter, Michael

1975 Internal Colonialism. Berkeley: University of California Press.

Hoult, Thomas Ford

1979 "The humanist perspective." In Scott McNall (ed.), Theoretical Hughes, Everett Perspectives in Sociology. New York: St. Martin's Press.

1958 Men and Their Work. New York: The Free Press.

Hughes, H. Stuart

1958 Consciousness and Society. New York: Vintage Books.

Illich, Ivan

1976 Medical Nemesis: The Expropriation of Health. New York: Pantheon Books.

Latour, Bruno and Stephen Woolgar

1979 Laboratory Life: The Social Cosntruction of Scientific Facts. Beverly Hills, Ca.: Sage Publications.

Leach, Edmund

1959 Political Systems of Highland Burma. Boston: Beacon Press.

1970 Claude Levi-Strauss. New York: The Viking Press.

Levi-Strauss, Claude

1966 The Savage Mind. Chicago: University of Chicago Press.

1967 "The structural study of myth." In C. Levi-Strauss, Structural Anthropology. Garden City, N.J.: Anchor Books. 
Mid-American Review of Sociology

Kriesberg, Louis

1962 "The bases of occupational prestige: the case of dentists." American Sociological Review 27:238-244.

McCarthy, John and Mayer Zald

1973 The Trend in Social Movements in America: Professionalization and Resource Mobilization, (Module) Morristown, N.J.: General Learning Press.

Marcuse, Herbert

1964 One-Dimensional Man. Boston: Beacon Press.

1968 "Industrialization and capitalism in the work of Max Weber." In Negations. Boston: Beacon Press.

Mead, George Herbert

1934 Mind, Self and Society. Chicago: University of Chicago Press.

Morris, Norval

1974 The Future of Imprisonment. Chicago: University of Chicago Press. Oberschall, Anthony

1973 Social Conflict and Social Movements. Englewood Cliffs, N.J.: Prentice-Hall.

Piaget, Jean

1971 Structuralism. New York: Basic Books.

Stoll, Clarice

1975 "Images of man and social control." In Ronald Akers and Richard Hawkins (ed.), Law and Control in Society. Englewood Cliffs, N.J.: Prentice-Hall.

Szasz, Thomas

1961 The Myth of Mental Illness. New York: Dell Publishing Company. Tilly, Charles

1969 "Collective violence in European perspective." In Hugh D. Graham and Ted Gurr (eds.), The History of Violence in America. New York: Bantam Books.

1978 From Mobilization to Revolution. New York : Addison-Wesley.

Weber, Max

1949 Methodology of the Social Sciences. Glencoe, Ill.: The Free Press.

Weinberg, Ian

1974 "Social problems that are no more." In Erwin Smigel (ed.), Handbook on the Study of Social Problems. Chicago: Rand McNally.

White, Hayden

1973 "Foucault decoded: notes from underground." History and Theory. 294-326.

Wilensky, Harold and Charles Lebaux

1958 Industrial Society and Social Welfare. New York: Russell Sage Foundation.

Wilson, James

1975 Thinking About Crime. New York: Vintage Books.

\section{THEORY CONSTRUCTION IN SOCIOLOGY: THE COMPETING APPROACHES}

\author{
Robert John \\ University of Kansas
}

Mid-American Review of Sociology, 1980, Vol. V, No. 1:15-36

Over the last thirty years a number of sociologists have addressed the prospects of transforming sociology into a truly scientific discipline. This project has been translated into an ongoing debate between various proponents of opposing viewpoints in the literature on construction. In this paper I propose to analyze and compare the three major approaches toward theory construction, and the methods to which they adhere. In accomplishing this task I will concentrate on three main exemplars of these competing approaches: "grounded" theory advanced by Barney G. Glaser and Anselm L. Strauss; "propositional" theory by Hubert M. Blalock; and "exact" theory by David Willer.

\section{BACKGROUND}

Recoiling from the sterile formalism of Talcott Parsons, Robert Merton (1949) made the call for "middle-range" theories, and those engaged in empirical endeavors proceeded to carry this injunction forward. This shift toward "middle-range" theories sought to avoid the dual pitfalls of speculation and the mere collection of empirical trivia. The sentiment that sociology would progress toward maturity as a science through modest short-range theoretical goals served to focus effort on the substantive areas of sociology. Merton believed that once solid theories had been developed for a number of the substantive areas they could then be unified into more comprehensive theoretical systems until the ultimate goal of grand theory was achieved.

The following decade represents the ascendence of quantitative methods and a corresponding decline of the qualitative methods that were common prior to 1940. In 1954 the first edition of Hans Zetterberg's On Theory and Verification in Sociology 